\title{
Tomasz Dudek*
}

\section{Brygada Legionów Polskich w bitwie pod Kostiuchnówką w lipcu 1916 r.}

Jesienią 1915 r. dowództwo armii austro-węgierskiej zdecydowało o rozpoczęciu kolejnej ofensywy na froncie wschodnim. Jej celem było ostateczne wyparcie oddziałów rosyjskich z okupowanych jeszcze terenów Galicji Wschodniej. Odrzucenie jednostek rosyjskich daleko na wschód umożliwiłoby przerzucenie większości sił na front bałkański, gdzie jednostki C.K. armii miały spore kłopoty w przełamaniu serbskiej obrony. Jako główny kierunek uderzenia szef sztabu C.K. Armii generał Konrad von Hötzendorf wybrał Wołyń.

Jeszcze na przełomie sierpnia i września 1915 r. armie państw centralnych ruszyły do ataku na froncie wołyńskim. Po początkowych sukcesach, do których niewątpliwie należy zaliczyć zajęcie Łucka, ofensywa została zahamowana. W trzeciej dekadzie września armia rosyjska przeszła do kontrofensywy, w wyniku czego udało się jej odzyskać Łuck. Dopiero atak połączonych oddziałów austro-węgierskich i niemieckich, wspierany także przez pułki legionowe, doprowadził ostatecznie do wstrzymania rosyjskiej ofensywy.

Patrząc z perspektywy czasu, państwom centralnym nie udało się w większości osiagnąć zakładanych celów. Nie powiodły się bowiem próby całkowitego wyparcia oddziałów rosyjskich z Wołynia oraz otwarcia sobie drogi w kierunku Morza Czarnego. Niewątpliwym sukcesem było natomiast odzyskanie Galicji oraz zadanie nieprzyjacielowi dużych strat, tak w ludziach, jak i sprzęcie ${ }^{1}$. W działaniach ofensywnych na Wołyniu bardzo aktywny

* dr; historyk, archiwista, bibliotekarz; zainteresowania badawcze: historia Krakowa i okolic, dzieje Kresów Wschodnich, stosunki polsko-ukraińskie, biografistyka, dzieje polityczne Polski w XIX i XX w., historia wojskowości polskiej w XX w.; e-mail: tdudek. dudek6@gmail.com

${ }^{1}$ Według ostrożnych szacunków podczas ofensywy do niewoli dostało się blisko milion żołnierzy rosyjskich, Stanisław Czerep, Bitwa pod Łuckiem. Walne starcie zbrojne 
udział wzięła I Brygada. Jednostka ta wywodziła się bezpośrednio z I Kompanii Kadrowej, której żołnierze wymaszerowali 6 sierpnia 1914 r. z krakowskich Oleandrów. Po powstaniu Naczelnego Komitetu Narodowego oddziały strzeleckie zostały przeformowane w 1 Pułk Piechoty. Jego żołnierze toczyli krwawe walki z Rosjanami, m.in. pod Krzywopłotami, Anielinem, Laskami, Łowczówkiem. Ostatecznie w grudniu 1915 r. Pułk przekształcił się w Brygadę. W pierwszej połowie 1915 r. jej żołnierze zajmowali pozycje nad Nidą. Dopiero w drugiej połowie maja 1915 r. oddziały I Brygady przystąpiły do działań ofensywnych. Brygada stoczyła wówczas ciężkie walki pod Kozinkiem i Konarami ${ }^{2}$. Jej dalszy szlak bojowy biegł przez Lubelszczyznę i Podlasie. Dnia 3 września 1915 r. w pościgu za wycofującym się nieprzyjacielem legioniści przekroczyli rzekę Bug w rejonie Włodawy, wkraczając tym samym na tereny historycznego Wołynia. Na przełomie września i października 1915 r. żołnierze I Brygady wraz z legionistami z II i III Brygady toczyli krwawe walki m.in. pod Jabłonka, Kamieniuchą, Kołodią, Kuklami, Kostiuchnówkąa ${ }^{3}$ Ostatecznie w listopadzie 1915 r. na froncie zapanował spokój, przerywany jedynie przez sporadyczny ostrzał artylerii i starcia patroli.

Sytuacja zaczęła się stopniowo zmieniać w czerwcu 1916 r. Rozpoczęta w pierwszych dniach czerwca ofensywa Brusiłowa po początkowych sukcesach została zatrzymana przez armie państw centralnych. Na początku lipca Rosjanie po przegrupowaniu przystapili do drugiej fazy operacji. Główne uderzenie skierowane zostało na pozycje legionowe. Nie przypadkiem. Rosjanie obok celów militarnych mieli również cele polityczne. Chcieli bowiem doprowadzić do całkowitego zniszczenia jednostek legionowych. Taki przebieg wypadków mógł bardzo ułatwić działania rosyjskiej dyplomacji, która starała się przedstawić w Europie Zachodniej sprawę polską jako wewnętrzną kwestię polityczną imperium rosyjskiego. W przededniu

kampanii 1916 r. na wschodnim teatrze wydarzeń militarnych pierwszej wojny światowej (4 czerwca - 10 lipca 1916 roku), Oświęcim 2014, s. 90-91.

${ }^{2}$ Szerzej na ten temat zob. Wacława Milewska, Janusz Nowak, Maria Zientara, Legiony Polskie 1914-1918, Kraków 1999.

${ }^{3}$ Z walk I brygady na Polesiu Wotyńskim, „Wiadomości Polskie” 1915, nr 54, s. 5-6. Wieś Kostiuchnówka do 1939 r. znajdowała się w powiecie łuckim, stosunkowo niedaleko od miasteczka i stacji kolejowej Czartorysk, Mieczysław Orłowicz, Ilustrowany przewodnik po Wolyniu, Łuck 1929, s. 182. 
rosyjskiego ataku w składzie I Brygady dowodzonej przez brygadiera Józefa Piłsudskiego znajdowały się następujące jednostki:

1 Pułk Piechoty - pod dowództwem pułkownika Edwarda Śmigłego-Ry$\mathrm{dza}^{4}$,

5 Pułk Piechoty - pod dowództwem podpułkownika Leona Berbeckiego,

7 Pułk Piechoty - pod dowództwem majora Albina Fleszara ps. Satyr ${ }^{5}$,

1 Pułk Ułanów w sile 4 szwadronów, pod dowództwem rotmistrza Władysława Beliny Prażmowskiego.

Ponadto w brygadzie były: kompania saperów, oddział telefoniczny, zakład sanitarny, urząd prowiantów ${ }^{6}$. Naprzeciwko pozycji legionowych stały poważne siły rosyjskie obejmujące trzy dywizje piechoty $(77,78,100)$, liczące w sumie ok. 23 tys. bagnetów i ok. 3 tys. szabel, a więc ponad trzykrotnie więcej niż wszystkie brygady legionowe. Również w artylerii przewaga rosyjska była przygniatająca. Wojska rosyjskie wspierało około 84 dział oraz nieustalona bliżej liczba moździerzy, podczas gdy 1 Pułk Artylerii legionowej miał ich zaledwie $26^{7}$.

Atak rosyjski skierowany na polskie pozycje zaczął się 4 lipca. Na legionistów I Brygady zajmujących stanowiska w rejonie Kostiuchnówki spadł wówczas huraganowy ogień artylerii. Początkowo ostrzał skoncentrował się głównie na pozycjach obsadzonych przez żołnierzy I batalionu 5 Pułku Piechoty ${ }^{8}$ kapitana Stanisława Zwierzyńskiego ${ }^{9}$. Wbrew obawom dowódcy

${ }^{4}$ Każdy z nich liczył po dwa bataliony - w skład każdego wchodziły po cztery kompanie. Wyjątkiem był VI batalion 7 Pułku, który miał tylko trzy kompanie. Ponadto w składzie każdego pułku znajdowała się kompania karabinów maszynowych.

${ }^{5}$ Istnienie tego pułku nigdy nie zostało uznane przez dowództwo austro-węgierskie, stąd we wszystkich oficjalnych zestawieniach publikowanych przez dowództwo C.K. armii w składzie I Brygady figurują jedynie 1 i 5 Pułk Piechoty. Dopiero z końcem maja 1916 r. Komenda Legionów oficjalnie usankcjonowała istnienie pułku, Jakub Hoffman, Walki o Redutę Pitsudskiego, „Rocznik Wołyński” 1931, t. II, s. 338.

${ }^{6}$ Wojskowe Biuro Historyczne Centralne Archiwum Wojskowe, Komenda Legionów, Raport z przebiegu walk pod Kostiuchnówką w dniach 4-8 lipca 1916 r., sygn. I-120-1-89, s. 4.

${ }^{7}$ Przemysław Waingartner, Kostiuchnówka 1916. Największa polska bitwa I wojny światowej, Łódź 2011, s. 35-36.

${ }^{8} \mathrm{~W}$ dalszych partiach tekstu zastosowano skrót „I/5 Pułku Piechoty”, tzn. I batalion 5 Pułku Piechoty. Analogicznie skróty zastosowano przy określaniu pozostałych batalionów piechoty legionowej.

${ }^{9}$ Stanisław Zwierzyński ps. Sław (1892-1916), przed wybuchem I wojny światowej studiował na Politechnice Lwowskiej. Wtedy też został członkiem Związku Strzeleckie- 
batalionu, straty nie były duże. W wyniku kilkugodzinnego ostrzału batalion miał zaledwie 4 rannych żołnierzy. Tak małe straty należało tłumaczyć tym, że w tym rejonie znajdowało się stosunkowo dużo tzw. granatników, czyli specjalnie zbudowanych schronów - odpornych na ogień artyleryjski, oraz wykopanych dołów - tzw. lisich jam. Przebywała w nich cała obsada pozycji, w okopach znajdowały się wyłącznie dyżurne posterunki ${ }^{10}$. Porucznik Franciszek Dubiel zapisał w swoim dzienniku, że „Ogień ten był tak gwałtowny, że zniszczył przeszkody przed okopami, a druty pozrywał i pozasypywał piaskiem"11. Pomimo silnego ognia żołnierze niecierpliwie oczekiwali rosyjskiego ataku.

Dowódca baonu, w celu lepszego zabezpieczenia zajmowanych pozycji, zarządził wysłanie patroli w kierunku dawnego dworu oraz ruin wsi Kostiuchnówka. Miały rozpoznać sytuację na przedpolu. Ostatnie wyruszyły około godz. 15.00. Ich dowódcy zameldowali po powrocie, że oddziały rosyjskie na przedpolu wyraźnie przygotowują się do natarcia ${ }^{12}$.

W godzinach popołudniowych ogień artyleryjski objął pozycje 7 Pułku Piechoty. Najbardziej ostrzeliwany był VI/7 Pułku Piechoty dowodzony przez kapitana Mariana Kukiela ${ }^{13}$. W swojej relacji, opublikowanej kilka lat później, napisał: „Ogień ciężkiej artylerii co najmniej dwóch baterii, leżał za nami, na nieobsadzonej drugiej linii, rowach łącznikowych, krawędziach leśnych. Nas zasypywały potężne odłamki"14. Po pewnym czasie przeciwnik zaczął prowadzić bezpośredni ogień zaporowy na tyły batalionu oraz w re-

go. Po wybuchu wojny wstąpił do Legionów Polskich. Służył kolejno jako dowódca V i VI batalionu. Podczas walk na Wołyniu dowodził I batalionem 5 Pułku Piechoty. Poległ w bitwie pod Kostiuchnówką w lipcu 1916 r. W okresie międzywojennym został pośmiertnie odznaczony Orderem Virtuti Militari oraz Krzyżem Niepodległości.

${ }^{10}$ Biblioteka Zakładu Narodowego im. Ossolińskich we Wrocławiu, Stanisław Tyrowicz, Frontowe zapiski i notatki osobiste ze służby w Komendzie Głównej Legionów Polskich (oddział łączności), rkps 15661/I, k. 69.

${ }^{11}$ Franciszek Dubiel, Dziennik wojenny 1916-1917, [w:] Idea i czyn. Drogi mielczan do niepodległości 1907-1918, oprac. Jerzy Skrzypczak, Mielec 2003, s. 143.

${ }^{12}$ Marian Dąbrowski, Kampania na Wotyniu 2 IX 1915 - 8 X 1916, Warszawa 1919, s. $115-116$.

${ }^{13}$ Marian Kukiel (1885-1973), legionista, historyk wojskowości, po 1918 r. oficer zawodowy Wojska Polskiego. Po zamachu majowym odszedł z armii. W latach 30. dyrektor Biblioteki Czartoryskich w Krakowie. Podczas II wojny światowej służył w Polskich Siłach Zbrojnych na Zachodzie. Po 1945 r. pozostał na emigracji.

${ }^{14}$ Marian Kukiel, Moje wspomnienia o Kostiuchnówce, „Polska Zbrojna” 1924, nr 213, s. 3. 
jon tzw. Polskiego Lasku ${ }^{15}$. W rezultacie polskie jednostki zostały całkowicie pozbawione łączności telefonicznej, której, pomimo wysiłków, nie udało się przywrócić. Bardzo silny ogień nieprzyjacielskiej artylerii ranił lub zabijał dokonujących napraw łącznościowców oraz nieustannie niszczył stale odtwarzaną sieć telefoniczną ${ }^{16}$. Pod ogniem rosyjskim znalazły się również okopy zajmowane przez żołnierzy I/5 Pułku Piechoty.

Wacław Lipiński ${ }^{17}$ zapisał, że „Na odcinku 2 kompanii i na wprost komendy batalionu roznosi się teraz istny szał ognia. Nie widać tam okopów, nie widać drutów, nie widać ludzi, nie widać nic - jeden rozwlekły dym, gęsty i czarniawy, nieprzenikniony, a w dymie tym słupy, słupy fontanny ognia!"'18.

O wiele gorsza sytuacja panowała w Polskim Lasku, gdzie znajdowało się dowództwo 5 Pułku Piechoty, sanitariat i jego II batalion dowodzony przez majora Tadeusza Furgalskiego ${ }^{19}$. Aleksander Łuczyński ${ }^{20}$ relacjonował „Widok budził grozę. Ciężkie pociski wybuchające na bagnie wyrzucały w górę fontanny czarnego błota, które padając kaskadą brył łomotały, jak pędzący

${ }^{15}$ Nazwa ta została nadana przez Niemców, którzy w ten sposób chcieli uczcić bohaterstwo polskich żołnierzy, którzy toczyli w tym rejonie szczególnie ciężkie walki jesienią 1915 r. W ten sposób wzgórze koło Kostiuchnówki otrzymało nazwę Polskiej Góry (Polenberg), pobliski lasek - Polskiego Lasku (Polenwald), zaś kładka na dopływie Garbachu nazwę Polskiego Mostu (Polenbrücke). Znajdujący się w pobliżu Lasku Polskiego niewielki lasek nazwano Laskiem Saperskim, dla upamiętnienia wysiłku saperów budujących linie obronne na tym odcinku frontu.

${ }^{16}$ Sprawozdanie Komendy I Brygady z boju pod Kostiuchnówkq, zestawił Hugo Zieliński, „Żołnierz Legionów i POW” 1937, z. 3, s. 15.

17 Wacław Lipiński (1889-1949), żołnierz Legionów Polskich, historyk, dyrektor Instytutu im. J. Piłsudskiego w Warszawie. Podczas kampanii wrześniowej szef propagandy Dowództwa Obrony Warszawy. Został zamordowany w więzieniu we Wronkach.

${ }^{18}$ Wacław Lipiński, Szlakiem I brygady. Dziennik żotnierski, Łomianki 2014, s. 318.

${ }^{19}$ Tadeusz Furgalski ps. Wyrwa (1890-1916), asystent przy Katedrze Geologii Uniwersytetu Jagiellońskiego, członek Związku Walki Czynnej oraz Związku Strzeleckiego. Podczas walk na Wołyniu dowódca II/5 Pułku Piechoty. Poległ w nocy z 6 na 7 lipca 1916 r. Pośmiertnie odznaczony Orderem Virtuti Militari oraz Krzyżem Niepodległości.

${ }^{20}$ Aleksander J. Łuczyński ps. Narbut (1890-1977), członek Polskich Drużyn Strzeleckich. W latach 1914-1917 służył w Legionach Polskich w 5 i 6 Pułku Piechoty. Po 1918 r. zawodowy oficer Wojska Polskiego. Podczas kampanii wrześniowej był dowódcą etapów armii Kraków. Po zakończeniu wojny obronnej przedostał się na Zachód, gdzie służył w Polskich Siłach Zbrojnych. Po 1945 r. osiadł w USA, gdzie zmarł. Za działalność niepodległościową został odznaczony Srebrnym Krzyżem Orderu Virtuti Militari oraz Krzyżem Kawalerskim Orderu Odrodzenia Polski. 
po bruku tabun rozhukanych koni" ${ }^{21}$. W Polskim Lasku nie było niestety w ogóle schronów wytrzymałych na ogień artylerii, tylko zwykłe ziemianki. Potężny ogień artylerii rosyjskiej powodował, że zawalały się one jedna za drugą, stąd też duże straty pośród żołnierzy 5 Pułku Piechoty, przewyższające te zadane jednostkom znajdującym się na pierwszej linii ${ }^{22}$. Wobec nasilającego się ognia rosyjskiej artylerii dowódca pułku podjął decyzję o wycofaniu się z Polskiego Lasku. Na miejscu pozostała jedynie kompania porucznika Włodzimierza Koniecznego, która straciła 5 żołnierzy, 15 innych odniosło natomiast lżejsze lub cięższe rany ${ }^{23}$.

Najgorzej było jednak na Reducie Piłsudskiego ${ }^{24}$. Porucznik F. Dubiel ${ }^{25}$ zapisał w swoim dzienniku, że zasieki i inne przeszkody:

...były już około godz. 12 tak bardzo zniszczone, a obsada placówki tak bardzo ogniem znękana, że pozostałych z niej pięciu zdrowych ludzi musiało placówkę opuścić. Wprawdzie komenda pułku podesłała natychmiast pluton z kompanii rezerwowej i pluton ten, wraz z wyżej wymienionymi pięcioma ludźmi pozostałymi z poprzedniej obsady pod komendą ppor. Chilewskiego placówkę zajął, ale wobec gradu ciężkich pocisków kierowanych na nią przez nieprzyjaciela, wobec zupełnego zniszczenia przeszkód między placówką a Redutą i zacieśniającego się coraz groźniej naporu nieprzyjaciół naokoło Reduty - na rozkaz komendy pułku placówkę opuszczono ponownie ${ }^{26}$.

Około godz. 13.00 nastąpiła krótka przerwa w ostrzale reduty. Obrońcy starali się ją wykorzystać do naprawienia szkód wywołanych przez bombardowanie artyleryjskie. Na reducie pojawił się sam dowódca I Brygady brygadier Józef Piłsudski. Komendant chciał się zapoznać bezpośrednio ze stanem umocnień oraz dodać otuchy swoim żołnierzom. Przewidując, że

${ }^{21}$ Aleksander Narbut-Łuczyński, U kresu wędrówki, Londyn 1966, s. 144.

22 Jan Sadowski, Bój legionów pod Kostiuchnówkq w dniach 4-6 lipca 1916 roku, „Bellona” (Warszawa) 1931, t. XXXVII, s. 404; Tadeusz Pannenko, Od Nidy do Styru. Z walk II baonu 5 pp I brygady, Warszawa 1917, s. 168.

${ }^{23}$ M. Dąbrowski, Kampania..., s. 116.

${ }^{24}$ Była to specjalnie wysunięta, umocniona placówka, której zadaniem była osłona podejścia na przeprawę przez rzeczkę Garbach. Stanowiła ona kluczowy element obrony, dając z jednej strony możliwość wglądu na przedpola sąsiednich odcinków, z drugiej zaś wspierania ich ogniem flankowym.

${ }^{25}$ Franciszek Dubiel (1883-1918), absolwent Politechniki Lwowskiej, członek Polskich Drużyn Strzeleckich, oficer I Brygady. Po kryzysie przysięgowym wcielony do armii austro-węgierskiej i skierowany na front włoski. Popełnił samobójstwo.

${ }^{26}$ F. Dubiel, Dziennik..., s. 145. 
właśnie tutaj pójdzie główne rosyjskie natarcie, postanowił być jak najbliżej zagrożonych stanowisk, aby móc skuteczniej dowodzić żołnierzami27.

Około godz. 18.00 ogień rosyjskiej artylerii kierowany na redutę osiagnął apogeum. Był to wyraźny znak, że należy się spodziewać rosyjskiego ataku. W sprawozdaniu dowództwa I Brygady czytamy:

Gęste masy przeciwnika, które w kilku po sobie następujących łańcuchach wyłoniły się od dworu Kostiuchnówki i z lasu na północ od dworu, podpuszczono blisko pod druty, po czym rozpoczęto masowy ogień karabinowy i karabinów maszynowych. Moskale rzucili się w popłochu do ucieczki. Uciekające masy nieprzyjaciela ostrzelał z flanki karabin maszynowy baonu kapitana Kukiela, zadając przeciwnikowi nadzwyczaj ciężkie i krwawe straty ${ }^{28}$.

Po zakończonym fiaskiem natarciu Rosjanie ponownie rozpoczęli huraganowy ogień artylerii, który spowodował spore straty.

Ziemianki jedna po drugiej zawalały się i tworzyły barykady utrudniające komunikację wewnętrzną. Poszczególne plutony, a nawet sekcje, wskutek zawalenia się okopów traciły ze sobą łączność. Odłamki granatów, min, walące się drzewa i belki raniły i kontuzjowały ludzi ${ }^{29}$.

W godzinach popołudniowych uaktywniła się wreszcie legionowa artyleria. Wsparcie obrońców przez własną artylerię nie było jednak sprawą prostą. Przebywający wówczas na punkcie obserwacyjnym Adam Papee napisał:

Nasza piechota strzela jak szalona, kierowanie ogniem naszej baterii jest ciężkie tym bardziej, że musi ona przenosić ogień na dalsze linie wroga, bo za blisko są oni naszych okopów, a do rowu naszej placówki, którą normalnie w czasie służby obchodziliśmy, już widać gołym okiem, jak wskakują bure szynele nieprzyjacielskiej piechoty ${ }^{30}$.

Najgorsza sytuacja panowała na stanowiskach zajmowanych przez żołnierzy baonu kapitana Zwierzyńskiego. Rosjanie wyparli z sąsiednich pozycji oddziały węgierskie i tym samym uzyskali możność odcięcia I/5 Pułku Piechoty od reszty polskich oddziałów. Dowódca sąsiedniego II batalionu major Wyrwa-Furgalski, widząc zaistniałą sytuację

${ }^{27}$ P. Waingartner, Kostiuchnówka 1916..., s. 53.

${ }^{28}$ Sprawozdanie Komendy I Brygady..., s. 15.

${ }^{29}$ Jan Sadowski, Walki o redutę Piłsudskiego, „Przegląd Piechoty” 1936, z. 5, s. 695.

${ }^{30}$ Muzeum Historyczne Miasta Krakowa, Adam Papee, Ze wspomnień legionowego artylerzysty 1914-1919, rkps 1908, s. 6. 
[...] porwał dwie kompanie, zaatakował Polską Górę. Uderzenie było potężne, w kilkanaście minut cała pozycja Polskiej Góry była w naszym ręku. Nie mogliśmy jednak jej utrzymać, tam były dwa bataliony [rosyjskie - dopisek T. D.], on miał tylko dwie kompanie i rezerw nie było. Wrócił do lasku z kilkudziesięciu jeńcami ${ }^{31}$.

Niestety, sukces batalionu majora Wyrwy-Furgalskiego był już mocno spóźniony, bowiem Rosjanie, wzmocnieni dodatkowymi siłami, przygotowywali nowe natarcie. Około godz. 18.00 ruszyło natarcie 400 Pułku Piechoty na główne pozycje I/5 Pułku Piechoty. Na podejściach do głównej linii obronnej batalionu rosyjska piechota uformowała kolumnę szturmową. Żołnierze idący w pierwszym szeregu próbowali za pomocą nożyc do cięcia drutu lub swoich długich płaszczy, narzucanych na zwoje drutu kolczastego, stworzyć wyłom w zasiekach. W tym czasie stanowili doskonały cel dla legionowej piechoty, która strzelała bardzo skutecznie. W krótkim czasie na przedpolu polskich pozycji pozostało wielu rannych i zabitych rosyjskich żołnierzy. Jedynie niewielkiej grupce udało się dotrzeć do polskich okopów, gdzie została ostatecznie zatrzymana ${ }^{32}$. Na odcinku I baonu Rosjanie kilkakrotnie podrywali się do szturmu. Za każdym razem byli odrzucani na pozycje wyjściowe ${ }^{33}$. W miarę upływu czasu położenie batalionu pogarszało się, wobec czego jego dowódca podjął decyzję o odwrocie. Oddział miał się wycofywać dwiema kolumnami. Pierwsza, w składzie 3 i 4 kompania pod wspólnym dowództwem porucznika Jana Hajca ${ }^{34}$, miała wycofać się przez Polski Most ${ }^{35}$, natomiast kompanie 1 i 2 dowodzone przez kapitana Zwierzyńskiego - przez kładkę. Straż tylną miał stanowić wydzielony pluton 3 kompanii podporucznika Aleksego Nehringa ${ }^{36}$. Niestety zanim zdążył zająć pozycje, został wraz ze swoim plutonem pochłonięty przez nacierające masy rosyjskiej piechoty ${ }^{37}$. Aby przedostać się na drugą stronę, najpierw

${ }^{31}$ T. Pannenko, Od Nidy..., s. 171.

32 Stanisław Czerep, Kostiuchnówka 1916, Warszawa 1994, s. 37-38.

33 S. Czerep, Kostiuchnówka..., s. 38-39; Adolf Kotarba, Pamiętnik żotnierski sierżanta I brygady Józefa Pitsudskiego, Warszawa 1938, s. 239-240.

${ }^{34}$ Jan Hajec (1891-1916), członek Sokoła i Polskich Drużyn Strzeleckich, poległ pod Kostiuchnówką w lipcu 1916 r.

${ }^{35}$ Biblioteka Zakładu Narodowego im. Ossolińskich we Wrocławiu, Stanisław Tyrowicz, Frontowe zapiski i notatki osobiste ze służby w Komendzie Głównej Legionów Polskich (oddział łączności), rkps 15661/I, k. 69.

36 Aleksy Nehring (1891-1916), student Politechniki Lwowskiej, członek Związku Strzeleckiego, poległ pod Kostiuchnówką w lipcu 1916 r.

${ }^{37}$ M. Dąbrowski, Kampania..., s. 125. 
trzeba było opanować oba mostki przerzucone przez rzekę. Kapitan Zwierzyński poderwał swoich żołnierzy do desperackiego ataku na bagnety, w wyniku którego mostki znalazły się w polskich rękach. Przeprawa dokonywała się w bardzo trudnych warunkach. Rosjanie szybko otrząsnęli się z zaskoczenia, ostrzeliwując przeprawiających się Polaków. Próbowali też zająć oba mostki. Pragnąc zapobiec ostatecznej katastrofie, kapitan Zwierzyński skrzyknął wokół siebie grupę oficerów i żołnierzy. Nadludzkim wysiłkiem udało im się powstrzymać atakującego nieprzyjaciela, umożliwiając tym samym odwrót reszcie batalionu ${ }^{38}$.

Wśród wycofujących się żołnierzy był sierżant W. Lipiński. Zapisał później, że tego co wówczas zobaczył, nie zapomni do końca życia. Cały teren po drugiej stronie rzeki pokryty był bowiem sinymi niebieskimi mundurami.

Rwie wszystko na mostek. Jedyna droga odwrotu, jedyny cel. Wokół zielone grząskie bagno. Na mostku krzyk straszliwy. Tam w mig, piorunem powybijano kolbami, porozdzielano bagnetami sołdatów, co już zaszedłszy z boku, zastąpili drogę. Ciśnięto w bagno wielkich ruskich chłopów, zasłano nimi most ${ }^{39}$.

Śladem wycofujących się żołnierzy I/5 Pułku Piechoty przez mostki przeprawili się również Rosjanie, zagrażając tym samym prawemu skrzydłu batalionu kapitana Kukiela. Atak na jego pozycje został jednak odparty, a Rosjanie ponieśli bardzo duże straty ${ }^{40}$. Dowódca batalionu, przekonany, że wątła linia polskiej obrony może zostać w każdej chwili przerwana przez nacierające oddziały nieprzyjaciela, zdecydował się na brawurowe zagranie taktyczne. Mianowicie rzucił do kontrataku kompanię porucznika Edwarda Rzeckiego-Zintha, wzmocnioną dwoma plutonami odwodowymi oraz kompanię porucznika Leopolda Lisa-Kuli ${ }^{41}$. Dzięki temu posunięciu udało się odrzucić atakujących Rosjan aż na Polską Górę ${ }^{42}$. Pomimo odparcia nie-

${ }^{38}$ P. Waingartner, Kostiuchnówka 1916..., s. 58; ANK, Archiwum Naczelnego Komitetu Narodowego, sygn. NKN 450, s. 294-295; Wojskowe Biuro Historyczne Centralne Archiwum Wojskowe, Komenda Legionów, Raport z przebiegu walk pod Kostiuchnówką w dniach 4-6 lipca 1916 r., sygn. I-120-1-89, s. 8-9.

${ }^{39}$ W. Lipiński, Szlakiem..., s. 323.

${ }^{40}$ P. Waingartner, Kostiuchnówka 1916..., s. 61.

${ }^{41}$ Leopold Kula ps. Lis (1896-1919), oficer 7 Pułku Piechoty. Po kryzysie przysięgowym wcielony do armii austro-węgierskiej. Po odzyskaniu niepodległości w Wojsku Polskim. Poległ w 1919 r. podczas walk z Ukraińcami.

${ }^{42}$ F. Dubiel, Dziennik..., s. 146; M. Kukiel, Moje wspomnienia o Kostiuchnówce, „Polska Zbrojna” 1924, nr 215, s. 3. 
przyjacielskiego ataku, batalion rozpoczynał powolny odwrót na drugą linię obrony. Spowodowane to było opuszczeniem dotychczasowych stanowisk przez żołnierzy 5 Pułku Piechoty, co mogło prowadzić do odcięcia batalionu od własnych oddziałów ${ }^{43}$. Z nadejściem nocy na odcinku zajmowanym przez VI/7 Pułku Piechoty zapanowała przejmująca cisza. Rosjanie wyczerpani całodziennym bojem, mając ponadto ogromne straty, zdecydowali się wstrzymać natarcie. Ciszę lipcowej nocy przerywały jeszcze przez jakiś czas pojedyncze strzały karabinowe dochodzące $\mathrm{z}$ dawnych pozycji $5 \mathrm{Pułku}$ Piechoty. To podporucznik Józef Warski ${ }^{44}$ - student Uniwersytetu Jagiellońskiego, nie zdoławszy wycofać się na drugą linię obrony, bronił się przez jakiś czas wraz z garstką żołnierzy 2 kompanii I/5 Pułku Piechoty ${ }^{45}$.

Odwrót 5 Pułku Piechoty spowodował, że zaistniała możliwość wyjścia na tyły 7 Pułku Piechoty broniącego Reduty Piłsudskiego ${ }^{46}$. Na rozkaz brygadiera jego żołnierze rozpoczęli w późnych godzinach wieczornych odwrót na drugą linię obrony. Ostatecznie pozycje na reducie opuszczono około godz. 22.30. Poszczególne kompanie wycofywały się w całkowitym porządku, najpierw czwarta, a potem trzecia. Odwrót osłaniali żołnierze 2 plutonu dowodzonego przez podporucznika Alfreda Greffnera. Odbywał się on bez najmniejszych przeszkód ze strony nieprzyjaciela ${ }^{47}$. Osłonę wycofujących się oddziałów miał stanowić szwadron 1 Pułku Ułanów, który zajął rezerwowe okopy na przyczółku mostowym w rejonie Wołczecka ${ }^{48}$.

W godzinach wieczornych na rozkaz brygadiera Piłsudskiego został wysłany patrol 1 Pułku Ułanów dowodzony przez chorążego Antoniego Ja-

${ }^{43}$ Sprawozdanie Komendy I Brygady..., s. 15.

44 Józef Warski (1890-1916), student UJ, członek „Zarzewia” i Polskich Drużyn Strzeleckich, od 1915 r. podporucznik 5 Pułku Piechoty.

${ }^{45}$ Gustaw Łowczowski, Bitwa pod Kostiuchnówka, „Bellona” (Londyn) 1956, z. 3, s. 14.

46 Tak nazywano umocniony i wysunięty w kierunku nieprzyjaciela punkt oporu znajdujący się nad Garbachem. Został on zbudowany przez żołnierzy II Brygady, którzy zajmowali go aż do kwietnia 1916 r. Po zluzowaniu dotychczasowej obsady służbę w tym miejscu przejęli żołnierze I Brygady. Na cześć swojego dowódcy nazwali to miejsce Redutą Piłsudskiego.

${ }^{47}$ Ilustrowana kronika legionów polskich 1914-1918, oprac. Eugeniusz Quirini, Stanisław Librewski, Warszawa 1936, s. 101.

${ }^{48}$ G. Łowczowski, Bitwa..., s. 15; J. Sadowski, Walki.., s. 697-698. 
błońskiego ${ }^{49}$. Ułani dotarli aż w rejon Polskiej Góry. Według raportu przekazanego do komendy brygady przez dowódcę patrolu, nie było tam stałej rosyjskiej załogi. Pojawiały się tylko i wyłącznie patrole rosyjskie. Chorąży Jabłoński przypuszczał, że wynikało to z dużych strat poniesionych w dotychczasowym boju, co spowodowało, że Rosjanie bardzo poważnie zastanawiali się nad sensem obsadzenia tej pozycji ${ }^{50}$.

Ze wszystkich jednostek wchodzących w skład I Brygady stosunkowo najmniej atakowany był 1 Pułk Piechoty dowodzony przez pułkownika E. Śmigłego-Rydza. Ostrzał na pozycje zajmowane przez ten pułk zaczął się podobnie jak na innych odcinkach około godz. 6.00, najsilniejszy na pozycje zajmowane przez żołnierzy III baonu, dowodzonego przez kapitana Wacława Wieczorkiewicza. Ogień rosyjskiej artylerii miał na celu zniszczenie ziemianek i okopów. Stosunkowo późno, bo dopiero o godz. 19.00 ruszyło natarcie. Nieprzyjaciel, wykorzystując naturalną osłonę, jaką stanowił zalesiony teren, zbliżył się na lewym skrzydle batalionu na odległość ok. 100-150 metrów. Dalej nie był w stanie podejść z powodu dość silnego ognia polskiej piechoty. Jeszcze trudniej było na prawym skrzydle. Atakujący zdołali tu podejść do polskich pozycji na odległość zaledwie około 400 metrów, po czym ich atak się załamał. Rosjanie ponieśli stosunkowo duże straty, legioniści zaś stracili ledwie kilku ludzi ${ }^{51}$.

Stosunkowo spokojnie było na prawym skrzydle 1 Pułku Piechoty. Okopani legioniści już od wczesnych godzin rannych byli ostrzeliwani przez rosyjską artylerię. Ten dokuczliwy ostrzał spowodował, że obsada pierwszej transzei skryła się w schronach i ziemiankach. W okopach pozostały natomiast niewielkie czujki. Około godz. 11.00 legioniści wzięli do niewoli trzech jeńców z 400 Pułku. Podczas przesłuchania zeznali oni, że pozycje 1 Pułku Piechoty atakuje cała 100 Dywizja Piechoty. Około godz. 19.00 spieszony oddział kawalerii zaatakował jedną z wysuniętych placówek. Jej załoga wsparta przez 4 kompanię dowodzoną przez podporucznika Władysława Langnera z łatwością odparła przeciwnika. Około godz. 23.00 polskie oddziały wycofały się na pozycję ryglową. W dotychczasowych transze-

\footnotetext{
${ }^{49}$ Antoni Jabłoński ps. Zdzisław (1896-1920), członek patrolu Beliny, porucznik 1 Pułku Ułanów, w 1920 r. dowódca 11 Pułku Ułanów. Zmarł wskutek ran odniesionych w bitwie pod Nową Sieniawką.

${ }^{50}$ Wacław Budzyński, Z pierwszym szwadronem 1 pułku ułanów pierwszej brygady legionów polskich, Warszawa 1920, s. 98.

${ }^{51}$ S. Czerep, Kostiuchnówka..., s. 44-45.
} 
jach pozostały jedynie wydzielone plutony chorążego Jarosława Szafrana i sierżanta Stefana Holinkowskiego. Oba wytrzymały na dotychczasowych pozycjach aż do godz. 14.00 dnia następnego. Do tego czasu sierżant Holinkowski zorganizował wypad na pozycje rosyjskie. W jego wyniku Polacy wzięli 18 jeńców ${ }^{52}$. Wobec coraz bardziej pogarszającej się sytuacji komendant Legionów generał Stanisław Puchalski zdecydował się na uruchomienie swojego odwodu, którym były I/6 Pułku Piechoty i II/6 Pułku Piechoty. Około godziny 18.00 dowodzący tymczasowo pułkiem major Andrzej Galica został wezwany na stanowisko dowodzenia generała Puchalskiego nad Garbachem. Zgodnie z otrzymanymi rozkazami oba bataliony miały się jak najszybciej przemieścić w rejon stacjonowania 1 Pułku Piechoty. Miały tam zająć drugą linię koło stanowiska ryglowego na Garbachu. Oba baony znalazły się na wyznaczonych pozycjach już około godz. $20.30^{53}$.

W późnych godzinach wieczornych położenie oddziałów I Brygady przedstawiało się bardzo groźnie. Rosjanie dzięki opanowaniu stanowisk polskich pod Kostiuchnówką w każdej chwili mogli rozpocząć nowe natarcie, a wtedy natrafiliby na odwrócony częściowo front VI/7 Pułku Piechoty oraz bardzo słabo obsadzone stanowiska drugiej linii obrony pomiędzy Polskim Laskiem a redutą. Aby wzmocnić wątłą linię obrony brygadier Piłsudski zdecydował się na ewakuację reduty, na której pozostawiono jedynie silne placówki. Zgodnie z otrzymanymi rozkazami w nocy z 4 na 5 lipca polskie jednostki miały przeprowadzić kontratak, którego celem było odebranie utraconych stanowisk. Jego powodzenie zależało od zabezpieczenia prawej flanki w rejonie Polskiej Góry. Specjalnie wysłane patrole potwierdziły, że stanowiska batalionu są obsadzone przez niecałą kompanię węierskich honwedów. Dopiero wówczas, kiedy ustalono sytuację w rejonie Polskiej Góry, dowódca brygady wydał rozkaz do rozpoczęcia kontrataku. Do jego przeprowadzenia przeznaczono II/5 Pułku Piechoty bez jednej kompanii oraz odwodowy II/6 Pułku Piechoty. Całością natarcia miał dowodzić major Wyrwa-Furgalski. Pod osłoną nocy do ataku ruszyła polska piechota. O ile udało się w miarę szybko zająć dawne pozycje na reducie, o tyle dalsze posuwanie się polskich oddziałów zostało powstrzymane przez ogień rosyjskich karabinów maszynowych. Sytuację polskich oddziałów pogorszyło wpro-

52 S. Czerep, Kostiuchnówka..., s. 45-46.

${ }^{53}$ Raport bojowy I/6 pp z walk pod Kostiuchnówka w dniach 4, 5, 6 lipca 1916 roku, zestawił Hugo Zieliński, „Żołnierz Legionów i POW” 1937, z. 2, s. 52. 
wadzenie przez dowództwo rosyjskie odwodowych batalionów. Kontratak rosyjskich jednostek odwodowych zagroził odcięciem najbardziej wysuniętego II/5 Pułku Piechoty. Atakujące kompanie zaczęły ponosić coraz większe straty, wycofując się ku mostowi. Położenie uratowała kompania znajdująca się w okolicach Polskiego Mostu, której przeciwuderzenie rzuciło Rosjan na pozycje wyjściowe. Pod osłoną ognia własnych karabinów maszynowych legionowe kompanie wycofywały się powoli na pozycje wyjściowe. Cofające się oddziały były zmuszone torować sobie drogę bagnetami. Widząc pogarszającą się sytuację, major Wyrwa rzucił do ataku kompanie odwodowe. Ich celem było nie tylko powstrzymanie rosyjskiego uderzenia, ale także osłonięcie odwrotu własnych oddziałów. Zamiar ten powiódł się całkowicie i około godz. 4.30 ostatni polscy żołnierze wycofali się na drugi brzeg rzeki Garbach. Próba odzyskania dawnych pozycji zakończyła się kompletnym fiaskiem, zginęło bądź odniosło rany wielu żołnierzy i oficerów. Szczególnie bolesna była śmierć porucznika W. Koniecznego - absolwenta krakowskiej Akademii Sztuk Pięknych, znanego rzeźbiarza, grafika i teoretyka sztuki ${ }^{54}$.

Rankiem 5 lipca jednostki I Brygady zgromadzone zostały na drugiej linii obrony. I tak w rejonie Polskiego Lasku skoncentrowały się bataliony 5 Pułku Piechoty dowodzonego przez podpułkownika L. Berbeckiego. Jednostka ta w pierwszym dniu bitwy poniosła największe straty, żołnierze byli przemęczeni, brakowało również amunicji. W sumie pułk przedstawiał siłę zaledwie jednego batalionu. Na lewo od pozycji zajmowanych przez żołnierzy Berbeckiego znajdowały się pozycje 7 Pułku Piechoty. Jednostka ta poniosła również duże straty w pierwszym dniu bitwy, choć nie tak wielkie jak 5 Pułk Piechoty. Szacowano je na 15-20\% stanu wyjściowego. Dalej były okopy obsadzone przez żołnierzy 1 Pułku Piechoty dowodzonego przez E. Śmigłego-Rydza. Jednostka ta zachowała stosunkowo dużą wartość bojową, ponieważ podczas pierwszego dnia bitwy poniosła dość niewielkie straty ${ }^{55}$.

Rankiem 5 lipca artyleria rosyjska rozpoczęła ponowny ostrzał polskich pozycji, który koncentrował się na prawym skrzydle 5 Pułku Piechoty. Do-

${ }^{54}$ ANK, Archiwum Naczelnego Komitetu Narodowego, sygn. NKN 450, s. 296; Wojskowe Biuro Historyczne Centralne Archiwum Wojskowe, Komenda Legionów, Raport z przebiegu walk pod Kostiuchnówką w dniach 4-6 lipca 1916 r., sygn. I-120-1-89, s. 10-11; Bitwa pod Kostiuchnówka w świetle prawdy historycznej, „Polska Zbrojna” 1924, nr 189, s. 3.

${ }_{55}$ Jan Sadowski, Bój legionów polskich pod Kostiuchnówka, „Bellona” (Warszawa) 1931, t. XXXVIII, s. 11-12. 
wódca brygady, zdając sobie sprawę ze słabości tego pułku, zdecydował się na jego zluzowanie przez 1 Pułk Piechoty. Jego dotychczasowe pozycje mieli objać spieszeni ułani Beliny-Prażmowskiego. Około godz. 14.00 na pozycje 5 Pułku Piechoty przybyły dwie kompanie legionowe z pułku Śmigłego. Niestety luzowanie nie zakończyło się pełnym sukcesem ze względu na utrzymujący się ogień rosyjskiej artylerii ${ }^{56}$. Pogarszająca się sytuacja w rejonie Kostiuchnówki spowodowała, że skierowano tam 3 Pułk Piechoty wchodzący w skład II Brygady Legionów. Rankiem 5 lipca żołnierze tej jednostki dowodzonej przez podpułkownika Henryka Minkiewicza ruszyli do ataku i mimo silnego ognia artylerii rosyjskiej zdołali odzyskać rejon Polskiej Góry. Jej obsadzenie bardzo poprawiło sytuację 5 Pułku Piechoty, którego prawe skrzydło w zasadzie nie miało żadnej osłony, gdyż drobne oddziałki austriackie, jakie znajdowały się na prawo od polskich pozycji, nie były $\mathrm{w}$ stanie powstrzymać ewentualnego rosyjskiego ataku ${ }^{57}$. Ogień artylerii rosyjskiej kierowany na pozycje 5 Pułku Piechoty w miarę upływu czasu zaczął przybierać na sile. Około godz. 17.30 pierwsze oddziały rosyjskie pojawiły się w rejonie Polskiego Lasku, gdzie znajdowało się stanowisko dowodzenia podpułkownika Berbeckiego. Około godz. 18.00 na pozycje zajmowane przez żołnierzy podpułkownika Berbeckiego oraz dwie wydzielone kompanie 1 Pułku Piechoty ruszyło natarcie rosyjskiej piechoty. Pomimo ogromnych strat polskie oddziały rozpoczęły powolny odwrót na trzecią linię obrony ${ }^{58}$. Polscy żołnierze mimo nadludzkich wysiłków nie byli w stanie powstrzymać nacierającego nieprzyjaciela. Uczestnik tych walk Tadeusz Pannenko zapisał później: „Moskale już w połowie lasku - już słychać dziki wrzask »Zdajsja« - odpowiedzią huk wystrzałów, błysk bagnetów, trzask rozwalanych łbów... Wybiegł z ziemianki Berbecki - zobaczyli go... Runął na niego tłum mongolski: »Dierży Kamandira! Dierży Berbeckawo«"! 59 . Dowódcę przed dostaniem się do rosyjskiej niewoli uratował brawurowy kontratak, który zorganizował pułkowy adiutant podporucznik Julian Hersztal. Rosjanie nie tylko zostali powstrzymani, ale także udało się uratować dowódcę pułku przed dostaniem się do rosyjskiej

${ }^{56}$ Sprawozdanie Komendy I Brygady..., s. 16.

${ }^{57}$ W. Milewska, J. Nowak, M. Zientara, Legiony Polskie..., s. 184; Biblioteka Zakładu Narodowego im. Ossolińskich we Wrocławiu, Stanisław Tyrowicz, Frontowe zapiski i notatki osobiste ze służby w Komendzie Głównej Legionów Polskich (oddział łączności), rkps 15661/I, s. 70.

${ }^{58}$ M. Dąbrowski, Kampania..., s. 137.

59 T. Pannenko, Od Nidy..., s. 174-175. 
niewoli ${ }^{60}$. Aby umożliwić odwrót 5 Pułku Piechoty brygadier Piłsudski nakazał wykonanie kontrataku kompani porucznika L. Lisa-Kuli. Jej żołnierzom udało się powstrzymać nieprzyjaciela w rejonie Lasku Saperskiego, a tym samym umożliwić odwrót resztek 5 Pułku Piechoty, 7 Pułku Piechoty oraz II/6 Pułku Piechoty. Dzięki kontratakowi kompanii odwodowej przeszły one most na Garbachu, zbierając się zgodnie z otrzymanymi rozkazami w rejonie Nowego Jastkowa ${ }^{61}$. Nieznany z nazwiska oficer legionowy, w liście z dnia 11 lipca 1916 r., pisanym ze szpitala w Kowlu, a skierowanym do sekretariatu Naczelnego Komitetu Narodowego, napisał: „Przez dwie doby Lasek Polski w którym staliśmy był pod ogniem huraganowym. Moskale wypuścili na nas około 4000 granatów ciężkich $18 \mathrm{~cm}$, szrapneli zaś i granatów z polowych armat ilość niezliczoną"62. Odwrót 5 Pułku Piechoty spowodował powstanie luki w pozycjach obronnych, która stopniowo się powiększała. W razie rosyjskiego ataku groziło to nieobliczalnymi konsekwencjami, dlatego też dowódca brygady zmienił wcześniejsze rozkazy i skierował szwadrony 1 Pułku Ułanów w okolice Wołczecka, gdzie spieszone szwadrony zajęły pozycje obronne między cmentarzem a wsią. Ułani przybyli w ostatnim momencie. Wysłane patrole starły się bowiem z podchodzącymi $\mathrm{w}$ ten rejon oddziałami rosyjskimi ${ }^{63}$. Niestety na miejscu nie było żadnych umocnień, na których mogłaby się oprzeć polska obrona. Wacław Budzyński, wówczas ułan pierwszego szwadronu, napisał:

Trzeba było wtenczas widzieć ułanów jak scyzorykami i kolbami manlicherów darli powierzchnię, byle by się doskrobać do miękkiego podłoża i czerpać go ręką. Łopaty przyszły od saperów później dopiero, kiedy zrobiliśmy już najtrudniejsze i każdy mógł w swym dołku strzeleckim klęknąc za małym przedpiersiem z piasku i darni ${ }^{64}$.

Odwrót 5 Pułku Piechoty postawił w bardzo trudnej sytuacji żołnierzy 7 Pułku Piechoty, bowiem Rosjanie zaczęli wówczas wychodzić na tyły jednostki. Wobec zagrożenia na tyłach rozpoczęto odwrót. Ukształtowanie

\footnotetext{
${ }^{60}$ M. Dąbrowski, Kampania..., s. 138.

${ }^{61}$ Sprawozdanie Komendy I Brygady..., s. 17-18.

${ }^{62}$ ANK, Archiwum Naczelnego Komitetu Narodowego, sygn. NKN 450, s. 290-291.

${ }^{63}$ G. Łowczowski, Bitwa..., s. 20-21.

${ }^{64} \mathrm{~W}$. Budzyński, Z pierwszym..., s. 101. Po pewnym czasie ułani otrzymali wzmocnienie w postaci kompanii technicznej Komendy Legionów, legionowej kompanii saperów oraz austriackiej kompanii saperów, Wojskowe Biuro Historyczne Centralne Archiwum Wojskowe, Komenda Legionów, Raport z przebiegu walk pod Kostiuchnówką w dniach 4-6 lipca 1916 r., sygn. I-120-1-89, s. 15.
} 
terenu wymusiło na obrońcach zmianę taktyki. Żołnierze, walcząc w niewielkich grupach dowodzonych przez oficerów lub podoficerów, starali się wykorzystać wszelkie naturalne przeszkody do prowadzenia działań obronnych. Jednocześnie stopniowo wycofywali się w kierunku zachodnim ${ }^{65}$. Odwrót żołnierzy 7 Pułku Piechoty spowodował, że w ogromnym zagrożeniu znalazło się stanowisko dowódcy pułku majora A. Fleszara. Na stanowisku dowodzenia znajdował się wówczas Felicjan Sławoj Składkowski6 ${ }^{66}$, który zapisał, że całą grupę uratował jeden z podoficerów, który wpadł na stanowisko, krzycząc, że żołnierze 5 Pułku Piechoty wycofali się już do Lasku Saperskiego. Jako ostatni szedł podpułkownik Berbecki, krzycząc, że do stanowiska dowodzenia 7 Pułku Piechoty zbliżają się rosyjskie tyraliery ${ }^{67}$. Ostatecznie oddziały 7 Pułku Piechoty wycofały się na trzecią linię obrony w rejon Lasku Saperskiego. Dowodzący wówczas VI baonem kapitan M. Kukiel wspominał, jak próbował zorganizować w tym rejonie nową linię obrony. Ogromną rolę w uporządkowaniu pułku odegrał wówczas jego lekarz F. Sławoj Składkowski, „[...] który z pistoletem w dłoni zatrzymywał uciekających żołnierzy i formował z nich tyralierę" ${ }^{68}$. Również sytuacja w rejonie zajmowanym przez żołnierzy 1 Pułku Piechoty nie była najlepsza. Od wczesnych godzin rannych jednostka znajdowała się bowiem pod silnym ostrzałem artylerii rosyjskiej. Równocześnie rosyjska piechota raz po raz podejmowała próby ataku na polskie pozycje, zakończone jednak niepowodzeniem. Dowódca pułku, wiedząc o tragicznej sytuacji w centrum i na prawym skrzydle polskich pozycji, podjął jednak decyzję o odwrocie. Jako pierwszy opuścił swoje pozycje I/1 Pułku Piechoty, którego żołnierze wycofali się na tzw. pozycję poprzeczna, łączącą prawe i lewe skrzydło polskiej obrony. Około godz. 21.00 batalion zajął stanowiska na drugiej linii obrony. W godzinach wieczornych opuścili dotychczasowe pozycje także żołnierze III/1 Pułku Piechoty ${ }^{69}$.

Po zapadnięciu zmierzchu walki ustały na całej linii. Pozycje zajmowane przez oddziały legionowe były niestety usytuowane bardzo niekorzyst-

${ }^{65}$ P. Waingartner, Kostiuchnówka 1916..., s. 75-76.

${ }^{66}$ Felicjan Składkowski ps. Sławoj (1885-1962), po 1918 r. używał nazwiska Sławoj Składkowski, dr medycyny, legionista, polityk - w latach 1936-1939 premier RP, od 1939 r. na emigracji.

${ }^{67}$ Felicjan Sławoj Składkowski, Moja stużba w brygadzie, Warszawa 1990, s. 356.

${ }^{68}$ M. Kukiel, Moje wspomnienie o Kostiuchnówce, „Polska Zbrojna” 1924, nr 218, s. 5.

${ }^{69}$ P. Waingartner, Kostiuchnówka 1916..., s. 80. 
nie. Na lewym skrzydle jednostki III Brygady w dalszym ciagu zajmowały pierwszą linię obrony, natomiast oddziały I Brygady w wyniku ciężkich walk zostały zmuszone do wycofania się na drugą linię obrony. Wszystko to powodowało, że w jednolitej dotąd linii obrony zaczęła się wytwarzać coraz większa luka, której ze względu na brak jakichkolwiek odwodów, komendant Legionów generał major S. Puchalski nie był w stanie zapełnić. W związku z tym, coraz bardziej stawała się realna perspektywa opuszczenia pozycji pod Kostiuchnówką ${ }^{70}$.

Noc z 5 na 6 lipca przebiegła w miarę spokojnie. Rankiem 6 lipca, pomimo zmęczenia, żołnierze 5 Pułku Piechoty zostali skierowani jako wzmocnienie prawego skrzydła 7 Pułku Piechoty. Niestety, ze względu na ogromne straty poniesione $\mathrm{w}$ dotychczasowych walkach, jego żołnierze nie byli w stanie obsadzić całej przydzielonej im długości pozycji. Pozostała część okopów była jedynie kontrolowana przez piesze patrole. Nie trzeba dodawać, że taka sytuacja stanowiła wielkie zagrożenie. W przypadku kolejnego rosyjskiego ataku polska linia obrony mogła się rozlecieć jak przysłowiowy domek z kart ${ }^{71}$.

Około godz. 9.00 rozpoczęło się pierwsze tego dnia natarcie rosyjskie. Skierowane ono zostało tym razem na pozycje obsadzane przez żołnierzy 7 Pułku Piechoty, których stanowiska znajdowały się w pobliżu młyna na Garbachu. Nieprzyjacielska piechota, wykorzystując istniejące w tym miejscu zarośla, zdołała stosunkowo blisko podejść pod polskie pozycje. Atak został z łatwością odparty przez obrońców, którzy brawurowym kontratakiem wyparli jednostki rosyjskie na drugi brzeg Garbachu ${ }^{72}$. W miarę upływu czasu zaczęła się pogarszać sytuacja na odcinku VI batalionu dowodzonego przez kapitana Józefa Olszynę Wilczyńskiego. Piechota rosyjska wdarła się bowiem w lukę pomiędzy pozycjami batalionu a 1 Pułku Piechoty. Widząc to, dowódca pułku rzucił do kontrataku kompanię odwodową, nieprzyjaciel został odparty, a ciągłość linii obronnej przywrócona ${ }^{73}$. Niestety oddziałom rosyjskim udało się przełamać pozycje austriackie w rejonie

${ }^{70}$ Ibidem, s. $80-81$.

${ }^{71}$ Wojskowe Biuro Historyczne Centralne Archiwum Wojskowe, Komenda Legionów, Raport z przebiegu walk pod Kostiuchnówką w dniach 4-6 lipca 1916 r., sygn. I-120-1-89, s. 19.

72 S. Czerep, Kostiuchnówka..., s. 73.

${ }^{73}$ M. Kukiel, Moje wspomnienie o Kostiuchnówce, „Polska Zbrojna” 1924, nr 220, s. 7. 
Wołczecka. Zmusiło to oddziały legionowe, z takim poświęceniem broniące dotąd swoich pozycji, do rozpoczęcia stopniowego odwrotu. Rosyjskie dowództwo, aby do reszty zniszczyć znienawidzone Legiony, zdecydowało się rzucić do szarży kilka szwadronów jazdy ${ }^{74}$. Świadkiem rosyjskiego ataku był ówczesny kapitan M. Kukiel. W jego relacji, opublikowanej kilka lat później, czytamy:

Ujrzałem obraz potężny niezapomniany, godny pędzla Wojciecha Kossaka. Cwałowały rosyjskie szwadrony w rozwiniętym szyku, lśniące szablami i lancami wśród gęsto pękających szrapneli artylerii naszej. [...] szalała nasza tyralierka, rozognieni, wściekli strzelali moi żołnierze zapamiętale hamowani przez dowódców ${ }^{75}$.

Rosyjski atak zakończył się kompletnym fiaskiem. Atakująca kawaleria poniosła bardzo duże straty, tak w ludziach, jak i koniach, spowodowane w dużej mierze przez ogień polskich karabinów maszynowych ${ }^{76}$.

Wobec coraz bardziej pogarszającej się sytuacji brygadier Piłsudski, jeszcze przed otrzymaniem oficjalnego rozkazu z Komendy Legionów, przystapił do przygotowania do odwrotu w kierunku Maniewicz. W związku z nadejściem stosownych rozkazów poszczególne jednostki rozpoczęły manewr odwrotowy. Około godz. 16.30 swoje pozycje opuściły bataliony 7 Pułku Piechoty, które nieatakowane przez przeciwnika, zaczęły się powoli wycofywać. O wiele gorsza sytuacja panowała na odcinku 1 Pułku Piechoty. Rosjanie zorientowali się bowiem, że polskie jednostki opuszczają dotychczasowe pozycje, dlatego też dowódca pułku rzucił do przeciwuderzenia dwie kompanie. Kontratak spełnił swoje zadanie, bowiem powstrzymał dalsze posuwanie się nieprzyjaciela, a pułkowi umożliwił spokojne odejście na kolejną rubież obrony ${ }^{77}$. Najbardziej dramatycznie przebiegał odwrót 5 Pułku Piechoty. Nieludzko zmęczeni żołnierze zmylili drogę pomiędzy wsiami Smołdowica i Siemieniucha. Zanim dowódca jednostki podpułkownik Berbecki zorientował się w sytuacji, minęły blisko dwie godziny. W pewnym momencie polska kolumna wpadła w zasadzkę. W walce zginął idący na czele major T. Wyrwa Furgalski, ciężko ranny został natomiast do-

\footnotetext{
${ }^{74}$ Stanisław Zaremba, Szarża pod Wołczeckiem, „Przegląd Kawaleryjski” 1936, z. 1, s. $18-19$.

${ }^{75}$ M. Kukiel, Moje wspomnienie o Kostiuchnówce, „Polska Zbrojna” 1924, nr 220, s. 7.

${ }^{76}$ Bitwa pod Kostiuchnówka w świetle prawdy historycznej..., s. 3.

77 J. Sadow ski, Bój legionów..., „Bellona” (Warszawa) 1931, t. XXXVIII, s. 46.
} 
wódca pułku podpułkownik Berbecki. Żołnierze wzięli rannego na płachtę namiotową, zaś ciało majora pozostało niestety na polanie, zabrano tylko jego dokumenty ${ }^{78}$.

Kiedy meldunek o sytuacji dotarł do Siemieniuchy, gdzie znajdowało się stanowisko dowodzenia Piłsudskiego, ten natychmiast rozkazał wysłać na spotkanie nadchodzącego pułku silne patrole i wozy dla rannych. Jednocześnie Belina-Prażmowski wziął pluton ułanów i wyruszył po ciało Wyrwy-Furgalskiego. Do miejsca krwawej potyczki już jednak nie dotarł, teren bowiem zajęli Rosjanie. Udało się jedynie odnaleźć i zabrać ze sobą dwóch rannych żołnierzy 5 Pułku Piechoty ${ }^{79}$. Po krótkim odpoczynku brygada ruszyła $\mathrm{w}$ dalszą drogę, kierując się zgodnie z otrzymanymi rozkazami na Trojanówkę. Odwrót osłaniał 1 Pułk Piechoty wraz z dywizjonem kawalerii dowodzonym osobiście przez Belinę-Prażmowskiego. Pod tą miejscowością została zaatakowana tylna straż brygady. Wywołało to oczywiście ogromną panikę wśród wycofujących się wraz z legionistami oddziałów austriackich, którą z trudem udało się opanować polskiemu dowództwu ${ }^{80}$. Ostatecznie rankiem 7 lipca wszystkie oddziały legionowe znalazły się na drugim brzegu Stochodu.

Jednostki C.K. armii poza nielicznymi wyjątkami spisały się w tej bitwie fatalnie. Łatwo wpadały w panikę, ustępowały z zajmowanych pozycji nawet pod najmniejszym naciskiem nieprzyjaciela. Nic dziwnego, że legioniści oceniali je jak najgorzej. Nieznany z nazwiska oficer legionów pisał w relacji dla sekretariatu Naczelnego Komitetu Narodowego, że podczas końcowej fazy walk odwrotowych Austriacy spalili most na Stochodzie,

[...] choć po drugiej stronie rzeki pozostała jeszcze kompania legionistów i kompania Prusaków. W ostatniej chwili udało się przerzucić pontony i uratować te kompanie. Major pruski mówił z tego powodu Puchalskiemu o Austriakach w obelżywych słowach $^{81}$.

${ }^{78}$ BJ, Tadeusz Kudliński, Notatki do dziejów legionów polskich, akc., rkps 328/97, k. 30 .

79 W. Milewska, J. Nowak, M. Zientara, Legiony..., s. 189. Ciało poległego majora pochowali Rosjanie na miejscu, o czym informowała wychodząca w Kijowie prasa, M. Dąbrowski, Kampania..., s. 151.

${ }^{80}$ W. Lipiński, Szlakiem..., s. 337-338.

${ }^{81}$ BJ, Zbiór dokumentów, wydawnictw i druków ulotnych dotyczących Legionów Polskich i Polskiej Organizacji Wojskowej, t. V, mps 224779-IV rara, k. 10. 
Czy dzisiaj, po blisko stu latach od tamtych wydarzeń, jesteśmy w stanie pokusić się o bilans bitwy pod Kostiuchnówką? Wydaje się, że tak. Znakomita postawa bojowa legionistów spowodowała, że Rosjanom nie udało się osiągnąć żadnego z zakładanych celów operacyjnych. Nie tylko nie byli $\mathrm{w}$ stanie zniszczyć polskich oddziałów, ale także z powodu poniesionych strat nie byli zdolni do kontynuowania działań ofensywnych. Dało to bezcenny czas dowództwu C.K. armii na sprowadzenie posiłków potrzebnych do ostatecznego powstrzymania nieprzyjaciela. W walkach tych w szczególny sposób wyróżnili się żołnierze I Brygady, która poniosła w niej zresztą największe straty ${ }^{82}$.

Wysiłek zbrojny legionistów w znaczący sposób przyczynił się do tego, że na politycznych salonach Europy coraz częściej zaczęto mówić o konieczności powstania niepodległej Polski. Dnia 5 listopada 1916 r. cesarze Wilhelm II i Franciszek Józef I wydali specjalną proklamację zawierająca obietnicę powołania Królestwa Polskiego. Niestety państwom centralnym nie chodziło wcale o utworzenie niepodległego państwa polskiego, lecz o pozyskanie rekruta do tworzonej armii polskiej, która w myśl planów Berlina i Wiednia miałaby wesprzeć wyczerpane dwuletnimi walkami przeciwko Rosji armie państw centralnych. Takie postawienie sprawy wywołało oczywiście ogromne protesty w krajach Europy Zachodniej i USA. Wkrótce zresztą także i tam zaczęto sobie zdawać sprawę z konieczności odbudowy niepodległego państwa polskiego. Zwrócił na to m.in. uwagę w swoim słynnym programie pokojowym (tzw. 14 punktów) prezydent USA Woodrow Wilson. Jego 13 punkt mówił o utworzeniu na ziemiach zamieszkałych przez ludność polską niepodległego państwa polskiego z dostępem do morza.

I to był chyba najbardziej wymierny efekt krwawych bojów legionowych. Gdyby nie męstwo i trud legionistów przebieg wypadków mógł być zupełnie inny. Nie tak odległa przyszłość miała pokazać, że marzenie pokoleń Polaków o własnym niepodległym państwie stało się rzeczywistością.

${ }^{82} \mathrm{~W}$ walkach pod Kostiuchnówką jednostki legionowe jako całość poniosły ogromne straty sięgające 2000 żołnierzy rannych, zabitych, zaginionych i wziętych do niewoli. Największe straty spośród wszystkich pułków legionowych poniósł 5 Pułk Piechoty. Stracił on w sumie 30 oficerów i 500 żołnierzy, czyli połowę swojego stanu wyjściowego. Równie duże straty poniósł 7 Pułk Piechoty. Spośród jednostek I Brygady stosunkowo najmniej ucierpiały 1 Pułk Piechoty oraz 1 Pułk Ułanów,W. Milewska, J. Nowak, M. Zientara, Legiony..., s. 191. Dokładna lista strat zob. szerzej: Lista strat Legionów Polskich, nr 7, od 1 lipca do 1 października 1916 r., Piotrków 1916. 


\section{BIBLIOGRAFIA}

\section{Źródla rękopiśmienne}

Archiwum Narodowe w Krakowie

Archiwum Naczelnego Komitetu Narodowego, sygn. NKN 450.

Biblioteka Jagiellońska

Tadeusz Kudliński, Notatki do dziejów legionów polskich, akc., rkps 328/97.

Zbiór dokumentów, wydawnictw i druków ulotnych dotyczących Legionów Polskich i Polskiej Organizacji Wojskowej, t. V, mps 224779-IV rara.

Biblioteka Zakładu Narodowego im. Ossolińskich

Stanisław Tyrowicz, Frontowe zapiski i notatki osobiste ze służby w Komendzie Głównej Legionów Polskich (oddział łączności), rkps 15661/I.

Muzeum Historyczne Miasta Krakowa

Adam Papee, Ze wspomnień legionowego artylerzysty 1914-1919, rkps1908.

Wojskowe Biuro Historyczne Centralne Archiwum Wojskowe

Komenda Legionów, sygn. I-120-1-89.

\section{Źródla drukowane}

Lista strat Legionów Polskich, nr 7, od 1 lipca do 1 października 1916, Piotrków: Departament Wojskowy Naczelnego Komitetu Narodowego, 1916.

\section{Prasa}

„Wiadomości Polskie” 1915.

„Polska Zbrojna” 1924.

\section{Opracowania}

Budzyński Wacław: Z pierwszym szwadronem 1 pułku ułanów pierwszej brygady legionów polskich. Warszawa: Główna Księgarnia Wojskowa, 1920.

Czerep Stanisław: Bitwa pod Łuckiem. Walne starcie zbrojne kampanii 1916 r. na wschodnim teatrze wydarzeń militarnych pierwszej wojny światowej (4 czerwca-10 lipca 1916 roku). Oświęcim: Napoleon V, 2014.

Czerep Stanisław: Kostiuchnówka 1916. Warszawa: Bellona, 1994.

Dąbrowski Marian: Kampania na Wotyniu 2 IX 1915 - 8 X 1916. Warszawa: Księgarnia Wojskowa, 1916.

Dubiel Franciszek: Dziennik wojenny 1916-1917. W: Idea i czyn. Drogi mielczan do niepodległości 1907-1918. Oprac. Jerzy Skrzypczak. Mielec: Wydawnictwo SCK, 2003, s. $143-169$.

Hoffman Jakub: Walki o Redutę Piłsudskiego. „Rocznik Wołyński” 1931, t. II, s. 321-369.

Ilustrowana kronika legionów polskich 1914-1918. Oprac. Eugeniusz Quirini, Stanisław Librewski. Warszawa: Główna Księgarnia Wojskowa, 1936.

Kotarba Adolf: Pamiętnik żotnierski sierżanta I brygady Józefa Piłsudskiego. Warszawa: Nakładem Tygodnika Wiarus, 1938. 
Lipiński Wacław: Szlakiem I brygady. Dziennik żołnierski. Łomianki: Wydawnictwo LTW, 2014.

Łowczowski Gustaw: Bitwa pod Kostiuchnówkq. „Bellona” (Londyn) 1956, z. 3, s. 3-24.

Milewska Wacława, Nowak Janusz, Zientara Maria: Legiony Polskie 1914-1918. Kraków: Księgarnia Akademicka - Wydawnictwo Naukowe, 1999.

Narbut-Łuczyński Aleksander: U kresu wędrówki. Londyn: Gryf, 1966.

Orłowicz Mieczysław: Ilustrowany przewodnik po Wołyniu. Łuck: Wołyńskie Towarzystwo Krajoznawcze i Opieki nad Zabytkami Przeszłości, 1929.

Pannenko Tadeusz: Od Nidy do Styru. Z walk II baonu 5 pp I brygady. Warszawa: Nakładem Jana Sowicza, 1917.

Raport bojowy I/6 pp z walk pod Kostiuchnówka w dniach 4, 5, 6 lipca 1916 roku. Zestawił Hugo Zieliński. „Żołnierz Legionów i POW” 1937, z. 2, s. 52-54.

Sadowski Jan: Bój legionów pod Kostiuchnówka w dniach 4-6 lipca 1916. „Bellona” (Warszawa) 1931, t. XXXVII, s. 375-417.

Sadowski Jan: Bój legionów pod Kostiuchnówkq w dniach 4-6 lipca 1916. „Bellona” (Warszawa) 1931, t. XXXVIII, s. 1-55

Sadowski Jan: Walki o redutę Pitsudskiego. „Przegląd Piechoty” 1936, z. 5, s. 655-699.

Sławoj Składkowski Felicjan: Moja służba w brygadzie. Warszawa: Bellona, 1990.

Sprawozdanie Komendy I Brygady z boju pod Kostiuchnówkq. Zestawił Hugo Zieliński. „Żołnierz Legionów i POW” 1937, z. 3, s. 14-20.

Waingartner Przemysław: Kostiuchnówka 1916. Największa polska bitwa I wojny światowej. Łódź: Agencja Reklamowa Grafservice, 2011.

Zaremba Stanisław: Szarża pod Wołczeckiem. „Przegląd Kawaleryjski” 1936, z. 1, s. 6-41.

\section{PODSUMOWANIE \\ I Brygada Legionów Polskich w bitwie pod Kostiuchnówką w lipcu 1916 r.}

W prezentowanym artykule autor starał się przedstawić walki I Brygady Legionów podczas bitwy pod Kostiuchnówką. Był to najkrwawszy bój stoczony przez polskich legionistów podczas I wojny światowej. Główny ciężar walki wzięła na siebie brygada Piłsudskiego, na którą dnia 4 lipca 1916 r. ruszyło główne uderzenie rosyjskie. Poszczególne pułki toczyły zaciekłe walki w obronie każdej pozycji. Do najtrudniejszych epizodów należała obrona Reduty Piłsudskiego przez żołnierzy 7 Pułku Piechoty, czy też zajadłe walki 5 Pułku Piechoty nad Garbachem i w rejonie Polskiego Lasku. Chociaż w efekcie morderczych walk I Brygada oraz pozostałe jednostki legionowe zostały zmuszone do wycofania się za Stochód, to jednak sama bitwa zakończyła się taktycznym zwycięstwem strony polskiej. Legioniści zadali armii rosyjskiej ogromne straty, nie dopuszczając przy tym do przerwania frontu i dając czas dowództwu C.K. armii na ściągnięcie posiłków. Krew przelana przez legionowego żołnierza w bitwie pod Kostiuchnówką nie poszła na marne. Na europejskich salonach coraz częściej zaczęto mówić o konieczności utworzenia niepodległego państwa polskiego. 


\section{SUMMARY}

\section{The I Brigade of the Polish Legions in the Battle of Kostiuchnówka in July 1916}

In the article, the author tries to present the fight of the I Brigade of the Polish Legions during the Battle of Kostiuchnówka. This was the bloodiest battle entered into by the Polish legionnaires during World War I. The main burden of the fighting was taken upon itself by Piłsudski's brigade, which, on 4 July 1916, was attacked by the Russian forces. Particular corps were engaged in fierce fighting in the defence of specific positions. The most difficult episodes included the defence of the Piłsudski Redoubt by soldiers of the $7^{\text {th }}$ Infantry Division, as well as the fierce fighting of the $5^{\text {th }}$ Infantry Division by the River Garbach and in the Polish Forest. Although the result of the murderous fighting of the I Brigade and other units of the legions was their forced retreat across the River Stochód, the Battle ended in a tactical victory for the Polish forces. The legionnaires inflicted huge losses on the Russian army, not allowing them to break through the front-line and buying time for the leadership of the C.K. Army to call up reinforcements. The blood lost by the soldiers in the Battle of Kostiuchnówka was not in vain. Throughout Europe, the necessity to create an independent Polish state was discussed more frequently.

SŁOWA KLUCZOWE: Kostiuchnówka, I Brygada, Józef Piłsudski, I wojna światowa, Legiony Polskie

KEY WORDS: Kostiuchnówka, I Brigade, Józef Piłsudski, World War I, Polish Legions 